\title{
BUSINESS PERFORMANCE OF HEALTH TOURISM SERVICE PROVIDERS IN THE REPUBLIC OF CROATIA
}

\author{
Sanela Vrkljan ${ }^{1}$ and Zvjezdana Hendija ${ }^{2}$ \\ ${ }^{1}$ Tourism Sector, Croatian Chamber of Economy; ${ }^{2}$ Department for Tourism, Faculty of Economics and Business, \\ Zagreb, Croatia
}

\begin{abstract}
SUMMARY - Health tourism can be generally divided into medical, health spa and wellness tourism. Health spa tourism services are provided in special hospitals for medical rehabilitation and health resorts, and include under medical supervision controlled use of natural healing factors and physical therapy in order to improve and preserve health. There are 13 special hospitals for medical rehabilitation and health resorts in Croatia. Most of them are financed through the state budget and lesser by sale on the market. More than half of their accommodation capacity is offered for sale on the market while the rest is under contract with the Croatian Health Insurance Fund. Domestic overnights are several times higher than foreign overnights. The aim of this study was to analyze business performance of special hospitals for medical rehabilitation and health resorts in Croatia in relation to the sources of financing and the structure of service users. The assumption was that those who are more market-oriented achieve better business performance. In proving these assumptions, an empirical research was conducted and the assumptions were tested. A positive correlation was proven in tested indicators of business performance of the analyzed service providers of health-spa tourism with a higher amount of overnight stays realized through sales on the market in relation to total overnight stays, with a greater share of foreign overnights in total of overnights and with a higher share of realized revenue on the market out of total revenue. The results of the research show that special hospitals for medical rehabilitation and health resorts that are more market-oriented are more successful in their business performance. These findings are important for planning the health and tourism policies in countries like Croatia.
\end{abstract}

Key words: Health tourism - economics; Hospitals, special; Rehabilitation; Health resorts; Croatia

\section{Introduction}

Health tourism helps people preserve and improve their physical, mental and spiritual health ${ }^{1}$. Vukonić and Cavlek ${ }^{2}$ defined health tourism as one's temporary change of permanent residence and travel to an appropriate health resort for various reasons such as prevention, treatment and rehabilitation. Health is the oldest and most powerful motive of tourist movements and almost the entirety of tourism can be considered as

Correspondence to: Sanela Vrkljan, Tourism Sector, Croatian Chamber of Economy, Rooseveltov trg 2, HR-10000 Zagreb, Croatia

E-mail: sanela.vrkljan@gmail.com

Received January 27, 2016, accepted March 16, 2016 health tourism in its broadest sense ${ }^{3}$. The change of physical and social environment, which is the result of tourism, has a healing effect ${ }^{4}$. The same is stated by Vitthal et al. ${ }^{5}$ defining health tourism as every trip that improves the health of an individual.

Globally, health tourism is showing above-average growth rates and the potential for further growth. The reason for this can be found in the present trend of population aging and the trend of healthy lifestyle by the growing middle class or unhealthy lifestyles (lack of free time, stress, fast and unhealthy food, technology, and other). In Europe in 2013, 18\% of the population were older than 65 , and it is expected that their share will rise to $28 \%$ by 2020 , with further increase ${ }^{6}$. Elderly population recognize the natural remedies 
and attractions available at a given destination as the factors affecting decision-making process ${ }^{7}$. These factors require a holistic approach to the development of medical tourism, which is beyond the scope of individual providers of specific health tourism services. Besides the elderly population, the average European health tourist is wealthy, educated, middle-aged, and willing to spend up to $130 \%$ more than the average guest $^{8}$. In addition, health tourism is less influenced by seasonality than other tourism segments.

Menvielle et al. ${ }^{9}$ divide health tourism into wellness tourism (esthetic surgery, spa programs, thalassotherapy, weight loss programs, programs for relaxation) and necessary medical tourism (rehabilitation and surgical tourism). Garcia-Altes ${ }^{10}$ points out that the concept of medical tourism is fairly broad because it includes a number of fields of healthcare and wellness. Tournois and Milliot ${ }^{11}$ consider that the necessary medical tourism is intended for patients who need or require interventions essential for life. For Müller and Lanz Kauffmann ${ }^{12}$, wellness tourism is planned and selected medical care dedicated to the preservation of health and well-being (esthetic surgery, spa, and thalassotherapy). In short, there is no universally accepted definition of health tourism and its sub forms, which contents may overlap with other definitions, depending on authors. Health tourism is similarly divided in Croatia. The tourism development strategy of the Republic of Croatia by $2020^{13}$ and the national health development strategy 2012-202014 divide health tourism into medical, health spa, and wellness tourism. These three terms should be distinguished from the main term of health tourism.

Wellness tourism services are usually provided in hotels and health resorts-spas, include the exercise of physical and spiritual balance, and have a preventive character. Medical tourism in Croatia takes place in medical clinics (mostly medium sized or smaller), clinics, polyclinics and special hospitals, and involves traveling to other destinations for partial surgery, dermatology, dentistry, ophthalmology, orthopedics, psychiatry and other treatments, along with other related services for medical care and recovery. Despite the fact that one of the main characteristics of tourism services is intangibility, in medical tourism, they should be tangible in the sense that the service will have physical consequences for patient-tourists. For example, in cosmetic surgery, results may have irreversible positive or negative physical effects ${ }^{9}$. From the tourism point of view, in contrast to medical tourism based on non-leisure motives that require various medical services with occasional additional service, other forms of health tourism are motivated by leisure, rest, and recreation. For these forms of health tourism, it is necessary to provide hospitality facilities and other complementary tourism offers by the service provider and at the destination. This type of health tourism is often criticized in Western medical circles because it is opposed to their health care system $^{15}$. There is often a competing conflict between providers of medical tourism in public and private ownerships, as well as between medicine and tourism in the appropriation of results, which is particularly emphasized in developing countries, including Croatia that is choosing this tourism segment as one of the main tourism development strategies. For this reason, medical tourism is often very overlooked or even hindered in development. In Croatia, health tourism is regulated by the Ministry of Health and Ministry of Tourism. It is therefore difficult to statistically monitor the performance of health tourism due to these overlapping ministries. No official statistical data provide a complete and detailed insight into this field of tourism. Overnights in health resorts are recorded in different ways, and in some accommodation capacities, the overnight stays are registered in a two-way manner, e.g., in tourism and health services ${ }^{16}$.

Therefore, the term of health tourism in Croatia generally applies only to the services of health spa tourism in health resorts (mainly at seaside resorts on the Adriatic coast), in special hospitals for medical rehabilitation, and in spas or thermal resorts (in inland Croatia). Services of health spa tourism include, under medical supervision, professional and controlled use of natural healing factors and physical therapy to treat, improve, rehabilitate and preserve health. This form of treatment, rehabilitation and prevention has a long tradition in Croatia, dating back to, for example in the case of Varaždin health resort, ancient times, and has been intensively developing since the second half of the $19^{\text {th }}$ century.

Currently, in Croatia there are 13 special hospitals $(\mathrm{SH})$ for medical rehabilitation and health resorts $(\mathrm{HR})$ as health spa tourism service providers: $\mathrm{SH}$ 
Daruvar Spa, SH Krapina Spa, SH Lipik, SH Naftalan, SH Stubica Health Resort, HR Topusko and SH Varaždin Health Resort, HR Istria Spa, HR Veli Lošinj, SH Thalassotherapia Crikvenica, SH Thalassotherapia Opatija, SH Biokovka Makarska and SH Kalos Vela Luka. They employ a preventative, rehabilitative, and curative approach. With the exception of HR Istria Spa, special hospitals for medical rehabilitation and health resorts are in the county ownership $^{17}$ and provide services through the Croatian Health Insurance Fund (CHIF) and partially by the non-budget, free market (market). With a tendency of decreasing, the share of CHIF total share of available beds is around $45 \%$ (unpublished research data of the Croatian Chamber of Economy, 2015). The quality standards of accommodation in particular, as well as of the food and beverages, and recreational facilities, with very few exceptions, do not meet the expectations of the international tourist demand ${ }^{18}$. In addition, a 'hospital' atmosphere often prevails in the facilities, and activities designed for CHIF patients and health tourists are not sufficiently separated. In order for spa and health tourism to be competitive on the international market, it is necessary to conduct categorization, accreditation and certification. In Croatia, a very small number of health institutions have market relevant international certificates (only few providers of medical tourism), and most of them only have ISO standards for internal quality processes, and only one health resort is categorized (unpublished research data of the Croatian Chamber of Economy, 2015). It is concluded that health spa tourism in Croatia is not internationally competitive. The Croatia's offer of health tourism is characterized by skilled workforce, good reputation of quality of medical and health services, price competitiveness, proximity to major emitting markets, safety of country to travel to, favorable climate and natural wealth with a number of healing factors, as well as a long tradition in health tourism. The next question is - what about business performance of special hospitals for medical rehabilitation and health resorts, the providers of health spa tourism?

\section{Materials and Methods}

The sample included all 13 special hospitals for medical rehabilitation and health resorts existing in
Croatia. Business performance was assessed using the following indicators: profit in total, profit per available bed and financial business performance - profit or loss. Correlation of the identified business performance indicators was tested according to the following variables: number of achieved CHIF overnights, share of CHIF overnights in total achieved overnights, share of market overnights in total achieved overnights, share of foreign overnights in total achieved overnights, number of achieved foreign overnights, amount of CHIF revenue, and share of market revenue in total revenue. The values of all tested variables were obtained through a structured questionnaire and refer to the year 2014.

All variables were assessed using descriptive statistics presented as median with interquartile range values. One-tailed Spearman's correlation coefficient was used to analyze the correlation between each variable and business performance. Spearman correlation coefficient as a nonparametric test was chosen because of a very small sample and no normality of data distribution. Spearman correlation coefficient sign (plus or minus) indicates a positive or negative correlation, and the value of the coefficient indicates the significance. If the value of the coefficient is above 0.3 , the variable is considered significant. The level of statistical significance was set at $p<0.05$. The SPSS 20.0 for Windows software was used to perform all analyses.

\section{Results}

According to descriptive statistics presented in Table 1, most special hospitals for medical rehabilitation and health resorts in Croatia have 101-243 rooms and 235-244 beds. The share of beds contracted with the CHIF ranged from $36 \%$ to $54 \%$, while the share of beds available for sale on the market ranged from $46 \%$ to $64 \%$. The share of foreign overnights (exclusively from market channel) was 7\%. The most common share of overnights by CHIF was $48 \%$, while the share of market overnights was $52 \%$. Nevertheless, the median market revenue was $20 \%$ of total revenue.

We analyzed whether special hospitals for medical rehabilitation and health resorts, as health spa tourism service providers, were more successful when they were more market-oriented. Table 2 shows results of Spearman correlation coefficients and p-values showing correlation between selected variables and busi- 
Table 1. Descriptive statistics analysis of general data of business performance of special hospitals for medical rehabilitation and health resorts in the Republic of Croatia in 2014

\begin{tabular}{|l|c|c|c|}
\hline & Median & $25^{\text {th }}$ percentile & $75^{\text {th }}$ percentile \\
\hline Total number of rooms (n) & 137.0 & 101.0 & 243.0 \\
\hline Total number of available beds (n) & 260.0 & 235.0 & 404.0 \\
\hline CHIF beds (n) & 120.0 & 77.0 & 140.0 \\
\hline Market beds (n) & 133.0 & 104.0 & 180.0 \\
\hline Share of CHIF beds in total number of beds (\%) & 47.0 & 36.0 & 54.0 \\
\hline Share of market beds in total number of beds (\%) & 53.0 & 46.0 & 64.0 \\
\hline Total number of overnights (n) & 64861.0 & 47946.0 & 76300.0 \\
\hline CHIF overnights (n) & 37890.0 & 26532.0 & 47748.0 \\
\hline Market overnights (n) & 22782.0 & 17481.0 & 37715.0 \\
\hline Share of CHIF overnights in total overnights (\%) & 48.0 & 26.0 & 70.0 \\
\hline Share of market overnights in total overnights (\%) & 52.0 & 30.0 & 74.0 \\
\hline CHIF domestic overnights & 37230.5 & 23187.0 & 44930.5 \\
\hline CHIF foreign overnights & 0.0 & 0.0 & 0.0 \\
\hline Market domestic overnights & 17488.0 & 13900.0 & 32352.0 \\
\hline Market foreign overnights & 3028.0 & 274.0 & 8198.0 \\
\hline Domestic overnights in total & 51531.5 & 38085.5 & 66572.5 \\
\hline Share of foreign overnights in total overnights (\%) & 7.0 & 0.0 & 15.0 \\
\hline CHIF revenue (HRK) & 12635057.0 & 10489756.0 & 17081356.0 \\
\hline Market revenue (HRK) & 5276787.0 & 4168941.0 & 15563482.3 \\
\hline Revenue in total (HRK)* & 24144327.0 & 21064220.0 & 30577040.0 \\
\hline Share of market revenue in total revenue (\%) & 20.0 & 18.0 & 30.0 \\
\hline Costs in total (HRK) & 30170715.0 & 20279995.0 & 38188284.0 \\
\hline Profit in total (HRK) & -663625.0 & -889700.0 & 443057.0 \\
\hline Profit per available bed (HRK) & -1508.7 & -4337.4 & 2614.1 \\
\hline
\end{tabular}

$\mathrm{CHIF}=$ Croatian Health Insurance Fund; *revenue in total consists of a wider set of revenues than market and CHIF revenue

ness performance of special hospitals for medical rehabilitation and health resorts. In order to determine business performance of special hospitals for medical rehabilitation and health resorts with correlation between selected variables and performance indicators, we analyzed whether the market-oriented special hospitals for medical rehabilitation and health resorts were more successful. A positive correlation was found with all the selected business performance indicators with a higher share of market overnights in total overnights, greater share of foreign overnights in total overnights, and higher share of market realized revenue in total revenue. For those providers of health spa services that were more oriented to the CHIF, a negative correlation was observed. Foreign overnights were only recorded in the market achieved overnights, while CHIF overnights did not include foreign overnights. The test results confirmed our initial assumption and it is concluded that business performance was higher in special hospitals for medical rehabilitation and health resorts that were more market-oriented.

Although Spearman correlation coefficient found statistical significance for multiple variables, $p$-value confirmed the significance of the number of CHIF overnights in correlation to profit or loss as indicators of business performance, to the share of market revenue in total revenue and to the realized profit per available bed. Therefore, additional statistical analysis of significant variables was conducted and is illustrated in Table 3. We found that in $50 \%$ of special hospitals 
Table 2. Correlation between selected variables and business performance of special hospitals for medical rehabilitation and health resorts in Croatia in 2014

\begin{tabular}{|l|c|c|c|}
\hline & \multicolumn{3}{|c|}{ Business performance } \\
\hline \multirow{2}{*}{ Number of CHIF overnights } & Profit & Profit per bed available & Profit or loss \\
\hline \multirow{2}{*}{ Share of CHIF overnights in total overnights } & -0.352 & -0.346 & -0.507 \\
\cline { 2 - 4 } & 0.119 & 0.123 & 0.038 \\
\hline \multirow{2}{*}{ Share of market overnights in total overnights } & -0.091 & -0.283 & -0.296 \\
\hline \multirow{2}{*}{ Share of foreign overnights in total overnights } & 0.384 & 0.174 & 0.163 \\
\cline { 2 - 4 } & 0.091 & 0.283 & 0.296 \\
\hline \multirow{2}{*}{ Number of foreign overnights } & 0.384 & 0.174 & 0.163 \\
\hline \multirow{2}{*}{ Revenue from CHIF } & 0.469 & 0.114 & 0.249 \\
\cline { 2 - 4 } & 0.147 & 0.362 & 0.217 \\
\hline \multirow{2}{*}{ Share of market revenue in total revenue } & 0.324 & 0.221 & 0.368 \\
\cline { 2 - 4 } & -0.352 & 0.245 & -0.423 \\
\cline { 2 - 4 } & 0.119 & -0.330 & 0.075 \\
\hline
\end{tabular}

CHIF = Croatian Health Insurance Fund

for medical rehabilitation and health resorts that performed with a loss, the number of CHIF overnights ranged from $37,230.5$ to $49,204.5$, while in those that gained profit the CHIF overnights ranged from 4.429 to 26.532 overnights. The median of CHIF overnights in special hospitals for medical rehabilitation and health resorts with negative business performance (loss) was 41,008 , and in those that achieved profit the median was 19,842 . The share of revenue generated on the market in total revenue of most of special hospitals for medical rehabilitation and health resorts that operated with a loss varied in the range of $16.0 \%$ to $26.5 \%$, while in those that earned profit it ranged from $20 \%$ to $59 \%$.

\section{Discussion}

To the best of our knowledge, no study to date has analyzed business performance of special hospitals for medical rehabilitation and health resorts as providers of health spa tourism in Croatia and wider. As stated in the Introduction section, there is no widely accepted definition of health tourism and forms of health tourism. The definitions vary from author to author,

Table 3. Differences in statistically significant variables according to profit or loss realized in special hospitals for medical rehabilitation and health resorts in Croatia in 2014

\begin{tabular}{|l|l|l|l|l|l|l|}
\hline & \multicolumn{3}{|l|}{ Business performance - loss } & \multicolumn{3}{l|}{ Business performance - profit } \\
\cline { 2 - 7 } & Median & $\begin{array}{l}25^{\text {th }} \text { percen- } \\
\text { tile }\end{array}$ & $75^{\text {th }}$ percentile & Median & $\begin{array}{l}25^{\text {th }} \text { percen- } \\
\text { tile }\end{array}$ & $75^{\text {th }}$ percentile \\
\hline $\begin{array}{l}\text { Number of CHIF over- } \\
\text { nights (HRK) }\end{array}$ & 41008.0 & 37230.5 & 49204.5 & 19842.0 & 4429.0 & 26532.0 \\
\hline $\begin{array}{l}\text { Share of market revenue } \\
\text { in total revenue (\%) }\end{array}$ & 18.0 & 16.0 & 26.5 & 22.0 & 20.0 & 59.0 \\
\hline
\end{tabular}

$\mathrm{CHIF}=$ Croatian Health Insurance Fund 
and therefore it is difficult to reliably track any statistical indicators and values, which are mostly shown as estimated values. The Global Spa Summit ${ }^{19}$ states that $16.8 \%$ of total revenues from tourism in the world come from health tourism, or medical, wellness and spa tourism, which means that one of six dollars from tourism in the world comes from health tourism. The Global Wellness Institute ${ }^{20}$ estimates that wellness tourism accounts for $71 \%$, thermal spa tourism resorts for $21 \%$, and medical tourism for $8 \%$ of total revenue of health tourism.

In Croatia, the providers of health spa tourism, primarily spas and other health tourism resorts offering thalassotherapy and thermal baths, are informally considered bearers of health tourism. Neighboring countries such as Slovenia, Austria and Hungary are internationally positioned as destinations of health tourism. Some distant countries have gone a step further and have a worldwide recognized image of their products such as Thai massages (Thailand), Turkish baths (Turkey, Jordan), yoga and meditation (India), and so on ${ }^{21}$. Croatia is still in the beginning, despite the long tradition of health tourism and the first spa from ancient times. In addition, besides Azerbaijan (Baku), Croatia (Ivanić Grad) is the only country in the world that has a site of mineral oil, naphthalene ${ }^{22}$. Slovenia, for example, has 15 health resorts and spas (a combination of health, wellness, recreational and other facilities), Hungary has 12 'spa' cities (including Budapest, offering traditional health resort with wellness facilities and recreation on the water), Austria has 30 towns offering a combination of health, wellness, recreational and entertainment facilities (marketed as Bad towns) ${ }^{23}$. Except for the initially mentioned 13 sites, Croatia has other spas that are not included in health spa tourism due to their offers (mostly wellness tourism). Croatia also has a wealth of natural therapeutic factors at numerous unused locations ${ }^{24}$.

As the service providers of health spa tourism are mainly county owned and are not included in the Master Plan of the Croatian Ministry of Health, they cannot apply for EU funds tenders, which could cofinance necessary improvements to upgrade their offers, as well as the construction of new buildings and facilities. This ownership hinders the possibility of new capital due to its non-profit orientation and no clear position concerning the interest of their possible privatization. In such conditions, other than bank loans, which carry a significant business risk, neither recapitalization from the public budget nor investments of private entrepreneurs can be considered as an option ${ }^{25}$. In neighboring countries, the majority of health resorts are in private ownership and have a strong market orientation. For example, Slovenia has low dependence on domestic health insurance touristpatients, as only $11.4 \%$ of total overnights were domestic health insurance tourist-patients in 2013. The share of domestic overnights in the total number of overnights was $57.6 \%$, with a tendency of growth of share of foreign guests in Slovenia ${ }^{26}$. The analysis conducted in the present study revealed the median of CHIF guests to be $48 \%$ versus $7 \%$ median of foreign guests in 2014. In addition to the existing restrictive ownership structure and outdated and inadequate properties according to the requirements of tourism demand, excessive dependence on CHIF and on domestic guests, weaknesses of health spa tourism in Croatia are also the lack of 'big picture' development vision at all levels, mismatching of relevant acts in the field of tourism and health, lack of market orientation, poor offer of a destination chain value that could affect additional spending, weak national promotion of this tourism segment, concession policy for thermal springs, lack of certification and accreditation, etc. On the other hand, the increasing expectations of international tourists, particularly the rapid development or already developed and positioned health tourism in neighboring countries and rapid development of technology, impose a pace that requires fast market orientation and adjustment of the offer, which requires significant investments and time.

In 2014, the most common number of CHIF overnights in special hospitals for medical rehabilitation and health resorts that achieved profit was 19,842 , and in those with the loss 41,008 overnights. Therefore, more successful were those in which the share of realized CHIF overnights was lower and which received a larger share of market revenue. Negative correlation between business performance of special hospitals for medical rehabilitation and health resorts was observed in all variables related to the CHIF (number of CHIF overnights, share of $\mathrm{CHIF}$ overnights in total number of achieved overnights, and amount of revenue realized from CHIF). 
Positive correlation was recorded between business performance and market variables (the share of market overnights in the total of overnights, the share of foreign overnights in the total of overnights, and the share of market-generated revenue in total revenue). It is concluded that health resorts and special hospitals for medical rehabilitation which are more market-oriented had better business performance than those more oriented towards CHIF.

\section{References}

1. Bartoluci M, Hendija Z. Investment management in Croatian Health Tourism. Journal of Accounting and Management. Croatian Accountant. 2012a;2(1):70-88.

2. Vukonić B, Čavlek N. Rječnik turizma. Zagreb: Masmedia; 2001. (in Croatian)

3. Kušen E, Klarić Z. Resursna osnova zdravstvenog turizma. In: Rožanić I, editor. I. međunarodni simpozij Opatija promotor zdravstvenog turizma. Zbornik radova. Opatija: Fakultet za menadžment u turizmu i ugostiteljstvu; 1997;233-44. (in Croatian)

4. Kušen E. Pozicioniranje medicinskog turizma u širi okvir zdravstvenog turizma. Turizam. 2011;59(1):93-7. (in Croatian)

5. Vitthal PC, Rupesh A, Sharma BR, Ramachandran M. Emerging trends and future prospects of medical tourism in India. J Pharm Sci Res. 2015;7(5):246-51.

6. European Commission. Demographic Challenge. 2013.

7. Tomasović Mrčela N, Borovac J, Vrdoljak D, Grazio S, Tikvica Luetić A, Tomek-Roksandić S. When elders choose: which factors could influence the decision-making among elderly in the selection of health tourism services? Med Hypotheses. 2015;Dec;85(6):898-904. doi: 10.1016/j.mehy.2015.09.013. Epub 2015 Sep 12.

8. Mintel. Health and Wellness Tourism in Europe. 2014. Available at: http://store.mintel.com/.

9. Menvielle L, Menvielle W, Tournois N. Medical tourism: the model of making decisions in choosing the services. Turizam. 2011;59(1):45-59.

10. Garcia Altes A. The development of health tourism services. Ann Tourism Res. 2005;32(1):262-6.

11. Tournois N, Milliot E. The Paradoxes of Globalization. Hampshire: Palgrave Macmillan. 2010;145-66.

12. Müller H, Lanz Kaufmann E. Wellness tourism: market analysis of a special health tourism segment and implications for the hotel industry. J Vacation Marketing. 2001;7(1):5-17.

13. Ministarstvo turizma RH. Strategija razvoja turizma u Hrvatskoj do 2020. godine. Official Gazette 55/13, 2013. Available at: http://narodne-novine.nn.hr/clanci/ sluzbeni/2013_05_55_11 19.html (10.01.2016). (in Croatian)
14. Ministarstvo zdravlja RH. Nacionalna strategija razvoja zdravstva Hrvatske 2012.-2020. Official Gazette 116/12. 2012. Available at: http://www.propisi.hr/files/file/ IVANA\%20-\%20PRO PISI\%20I/956_708\%20Nacionalna. pdf (10.01.2016). (in Croatian)

15. Brun N, Deau X, Roffé JL. Tourisme médical: la médicine low cost? Médecins. 2009. Available at: http://bulletin.conseilnational.medicin.fr/article.php3?id_article=273. (in French)

16. Bartoluci M, Hendija Z. Stanje i perspektive razvoja zdravstvenog turizma u Republici Hrvatskoj. Međunarodna konferencija Stanje i mogućnosti zdravstvenog i sportskorekracijskog turizma. Čakovec: Međimursko veleučilište. 2012b:10-22. (in Croatian)

17. Telišman Košuta N, Ivandić N, Kunst I, Marković I. Akcijski plan razvoja zdravstvenog turizma. Zagreb: Institut za turizam. 2015. Available at: http://www.mint.hr/ UserDocsImages/150608_AP_\%20Zdravstveni\%20turizam.pdf (15.01.2016). (in Croatian)

18. Telišman $\mathrm{N}$, et al. Konkurentska pozicija zdravstvenog turizma. Zagreb: Institut za turizam i Hrvatska gospodarska komora. 2005:34. (in Croatian)

19. Global Spa Summit. Wellness Tourism and Medical Tourism: Where do Spas fit? Research Report. 2011. Available at: http://www.glogalspaandwellness summit.org/images/stories/pdf/spas_wellness_medical_tourism_report_final.pdf (20.01.2016).

20. Global Wellness Institute. Global Tourism Industry - Statistics and Facts. 2013. Available at: http://www.globalwellnessinstitute.org/press-room/statistics-and-facts/ (20.01.2016).

21. Smith M, Puczko L. Health and Wellness Tourism. Oxford: Butterworth-Heinemann, Elsevier. 2009:52.

22. Kušen E. Pozicioniranje medicinskog turizma u širi okvir zdravstvenog turizma. Turizam. 2011;59(1):93-7. (in Croatian)

23. Telišman Košuta N, Ivandić N, Kunst I, Marković I. Akcijski plan razvoja zdravstvenog turizma. Zagreb: Institut za turizam. 2015:19-25. Available at: http://www.mint.hr/ UserDocsImages/150608_AP_\%20Zdravstveni\%20turizam.pdf (15.01.2016).

24. Ivanišević G. Prirodne mogućnosti razvitka wellness ponude $\mathrm{u}$ Hrvatskoj. Presented at the Meeting of Wellness Tourism Section at CCE. 2008. Available at: http://hgk.biznet.hr/hgk/tekst. php?a=b\&page=tekst\&id=1931 (10.4.2011.). (in Croatian)

25. Telišman Košuta N, Ivandić N, Kunst I, Marković I. Akcijski plan razvoja zdravstvenog turizma. Zagreb: Institut za turizam. 2015:45. Available at: http://www.mint.hr/ UserDocsImages/150608_AP_\%20Zdravstveni\%20turizam.pdf (15.01.2016). (in Croatian)

26. Vesenjak P. Development of the spa tourism in Slovenia - experiences from the transition period and after joining the EU. $4^{\text {th }}$ Balkan Spa Summit. Tuhelj. 2014. 
Sažetak

\section{USPJEŠNOST POSLOVANJA PRUŽATELJA USLUGA LJEČILIŠNOG TURIZMA U REPUBLICI HRVATSKOJ}

\section{S. Vrkljan i Z. Hendija}

Zdravstveni turizam je načelno moguće podijeliti na medicinski, lječilišni i wellness turizam. Usluge lječilišnog turizma se pružaju u specijalnim bolnicama za medicinsku rehabilitaciju i lječilištima, a uključuju pod liječničkim nadzorom stručno i kontrolirano korištenje prirodnih ljekovitih činitelja i fizikalne terapije radi unapređenja i očuvanja zdravlja. U Hrvatskoj posluje 13 specijalnih bolnica za medicinsku rehabilitaciju i lječilišta koja su većinom financirana iz državnog proračuna i manje iz prihoda ostvarenih izravnom prodajom na tržištu, premda se više od polovice njihovih smještajnih kapaciteta slobodno prodaje na tržištu, dok su ostali pod ugovorom s Hrvatskim zavodom za zdravstveno osiguranje. U strukturi noćenja domaća noćenja su višestruko zastupljenija od stranih. Cilj rada je bio analizirati uspješnost poslovanja specijalnih bolnica za medicinsku rehabilitaciju i lječilišta u Hrvatskoj u odnosu na izvore financiranja i strukturu korisnika usluga. Pretpostavke rada bile su da su poslovno uspješniji oni koji su više tržišno orijentirani. U dokazivanju tih pretpostavki provedeno je empirijsko istraživanje, a pretpostavke su testirane primjenom Spearmanova koeficijenta korelacije. Dokazana je pozitivna korelacija kod testiranih pokazatelja uspješnosti poslovanja analiziranih pružatelja usluga lječilišnog turizma s većim udjelom noćenja ostvarenim prodajom na tržištu u ukupno ostvarenim noćenjima s većim udjelom stranih noćenja u ukupno ostvarenim noćenjima te s većim udjelom tržišno ostvarenog prihoda u ukupnom prihodu. Može se zaključiti kako su poslovno uspješnije one specijalne bolnice za medicinsku rehabilitaciju i lječilišta koja su više tržišno orijentirana. Rezultati ovoga istraživanja su važni za planiranje zdravstvene politike i politike turizma u državama poput Hrvatske.

Ključne riječi: Zdravstveni turizam - ekonomija; Bolnice, specijalne; Rehabilitacija; Lječilišta; Hrvatska 